Paedagogia Christiana

2/30 (2012) - ISSN 1505-6872

Anna Szylar*

Tarnobrzeg

\title{
Ideały wychowawcze w klasztornych szkołach żeńskich w okresie potrydenckim do początków XIX wieku
}

Tematyka niniejszych rozważań dotyczy wychowania dziewcząt na pensjach i w szkołach prowadzonych w klasztorach żeńskich na terenie przede wszystkim Małopolski, obejmującej obszar województw krakowskiego, sandomierskiego i lubelskiego.

Zakres chronologiczny omawianych problemów zawiera się w granicach pomiędzy schyłkiem XVI wieku a 1815 rokiem, a o przyjętych ramach chronologicznych zadecydowały następujące czynniki. Ostatnie dziesięciolecie XVI wieku stanowiło czas, kiedy na terenie Małopolski, obejmującej obszar dawnego biskupstwa krakowskiego, biskup krakowski Jerzy Radziwiłł rozpoczął wdrażanie postanowień reformy trydenckiej w zakresie reorganizacji zakonów żeńskich, a tym samym określone zostało miejsce szkoły klasztornej i nowe zasady jej funkcjonowania. Kolejny punkt zwrotny przypada na lata 80 . XVIII wieku, gdy na ziemiach polskich, zajętych w wyniku I rozbioru przez Austrię, rozpoczęto wdrażanie w szkolnictwie reform józefińskich, polegających między innymi na zmianie statusu istniejących szkół żeńskich z klasztornych na tak zwane normalne, podporządkowaniu ich nadzorowi świeckiemu, wprowadzeniu jednolitych programów nauczania i systemu klasowo-lekcyjnego oraz języka niemieckiego, najpierw jako przedmiotu nauczania, a po trzecim rozbiorze jako języka wykładowego. Rozszerzenie wpływów austriackich na ziemiach polskich, połączone z re-

* Dr Anna Szylar, starszy wykładowca w Państwowej Wyższej Szkole Zawodowej im. prof. S. Tarnowskiego w Tarnobrzegu. 
organizacją szkolnictwa na obszarach anektowanych w wyniku trzeciego rozbioru, nastapiło po 1795 i trwało do 1809 roku, wtedy bowiem natapiło włączenie Galicji Zachodniej, obejmującej ziemie na północ od Wisły, do Księstwa Warszawskiego. Każda zmiana przynależności państwowej powodowała przeobrażenia systemu szkolnego oraz wpływała na obowiązujący wzorzec wychowania i edukacji. Dlatego zasadnym wydaje się prześledzenie funkcjonowania szkolnictwa żeńskiego pod kątem realizowanych w ciągu przeszło dwóch wieków ideałów wychowania.

Rozważania przeprowadzone zostały w oparciu o źródła archiwalne i publikacje powiązane tematycznie z omawianym zagadnieniem. Wśród najważniejszych archiwaliów należy wymienić regulaminy, plany i programy nauczania, kroniki klasztorne i szkolne, zalecenia władz kościelnych, zakonnych i świeckich oraz inne rozproszone informacje źródłowe. Spośród publikacji naukowych na uwagę zasługują prace dotyczące szkoły krakowskich prezentek $^{1}$, klarysek ${ }^{2}$ i norbertanek ${ }^{3}$ oraz sandomierskich benedyktynek ${ }^{4}$.

W okresie od schyłku XVI wieku do 1815 roku na terenie Małopolski istniały zakony wywodzące się z tradycji augustiańskiej, benedyktyńskiej, franciszkańskiej, karmelitańskiej i zgromadzenia zakonne czynne ${ }^{5}$. Liczba domów zgromadzeń żeńskich, należących do wymienionych zakonów, ulegała w ciągu przeszło dwóch wieków zmianie. Około 1600 roku funkcjonowało tu 13 klasztorów ${ }^{6}$, w ciągu półwiecza powstało 14 następnych ${ }^{7}$, ale

${ }^{1}$ R. Gąsior, T. Matuła, Szkoła Sióstr Prezentek w Krakowie w latach 1627-1918, Lublin 1998, s. 27-198.

${ }^{2}$ E. Sander, Działalność edukacyjna i wychowawcza krakowskich klarysek, Kraków 2010, s. 9-24, 135-144.

${ }^{3}$ A. Rybak, H. Otorowska Wrońska, Szkoła PP. Norbertanek w Krakowie, Warszawa 1988, s. 7-18.

${ }^{4}$ A. Szylar, Działalność oświatowa benedyktynek sandomierskich w latach 1616-1865, Lublin 2002, s. 63-78, 91-97.

${ }^{5}$ M. Borkowska, Zakony żeńskie w Polsce w epoce nowożytnej, Lublin 2010, s 104.

${ }^{6}$ Były to następujące klasztory: tradycji augustiańskiej (dalej t.a.) - norbertanek w Busku, Imbramowicach i na Zwierzyńcu pod Krakowem, dominikanek w Krakowie tzw. Dom Mniejszy i Dom Większy, duchaczek w Krakowie, brygidek w Lublinie, augustianek na Kazimierzu w Krakowie; tradycji benedyktyńskiej (t.b.) - benedyktynek w Staniątkach; tradycji franciszkańskiej (t.f.) - bernardynek w Krakowie przy kościele św. Agnieszki i przy kościele św. Kolety oraz klarysek w Krakowie i Starym Sączu.

7 W I poł. XVII w. miała miejsce fundacja następujących klasztorów: t.a. - norbertanek w Krakowie na ul. Wiślnej, bernardynek w Tarnowie, Lublinie, Drzewicy i Krakowie przy kościele św. Józefa, dominikanek w Krakowie na Gródku; t.b. - benedyktynek w Sandomierzu, 
już w latach 1650-1700 miała miejsce tylko jedna fundacja ${ }^{8}$. W I połowie XVIII stulecia założone zostały cztery zakonne domy żeńskie, będące ostatnimi fundacjami w tym stuleciu9. Od lat 80. obserwujemy zmiany w ilości klasztorów żeńskich, spowodowane kasatami prowadzonymi najpierw przez Austriaków ${ }^{10}$, następnie przez prymasa Michała Jerzego Poniatowskiego ${ }^{11}$, a w dalszej kolejności przez władze Księstwa Warszawskiego ${ }^{12}$. Skutkiem kasat było zmniejszenie się liczby klasztorów żeńskich w Małopolsce z 31 w 1772 do 22 w 1815 roku $^{13}$.

Przez cały omawiany okres jedynie karmelitanki bose nie prowadziły szkół, we wszystkich pozostałych konwentach zakonnice zajmowały się wychowaniem i edukacją dziewcząt świeckich. Do czasu wprowadzenia przez Austriaków reform oświatowych szkoły miały charakter zamknięty, znajdowały się wewnątrz klauzury w wyznaczonej części klasztoru, w związku z tym dziewczęta nie miały możliwości jej opuszczenia. Sam termin „szkoła” był w owym czasie raczej umowny, ponieważ dotyczył „panien świeckich" zamieszkujących w pensjonacie, nauczanych i wychowywanych przez zakonnice zgodnie z zasadami wynikającymi z przepisów zakonnych i obowiązujących zwyczajów klasztornych, bez podziału na klasy i bez określonych z zewnątrz programów nauczania. Od schyłku XVIII stulecia następowało powolne oddzielanie szkoły od pensjonatu, naukę podejmowały nie

Radomiu oraz w Krakowie (dom filialny klasztoru ze Staniątek); t.f. - klarysek w Chęcinach; tradycji karmelitańskiej (t.k) - karmelitanek bosych w Krakowie przy kościele św. Marcina, w Lublinie przy kościele św. Józefa i kościele Niepokalanego Poczęcia NMP; zgromadzenia czynne (z.cz.) - prezentek w Krakowie.

${ }^{8}$ t.a. - wizytek w Krakowie.

9 t.a. - wizytek w Lublinie; t.k. - karmelitanek bosych w Krakowie na Wesołej; z.cz. szarytek w Krakowie i Lublinie.

${ }^{10}$ Cesarz Józef II podpisał dekret kasacyjny znoszący klasztor klarysek w Starym Sączu (1782) i bernardynek w Tarnowie (1782), w dalszej kolejności Austriacy skasowali klasztor norbertanek w Krakowie na ul. Wiślnej (1803) i karmelitanek bosych przy kościele św. Józefa w Lublinie (1806).

${ }^{11}$ Prymas Michał Jerzy Poniatowski skasował klasztor karmelitanek bosych przy kościele św. Marcina w Krakowie (1787), bernardynek przy kościele św. Agnieszki w Krakowie (1788), zamknął nowicjat augustiankom, dominikankom, duchaczkom, bernardynkom przy kościele św. Kolety. Planował też kasatę dwóch konwentów dominikanek krakowskich (Dom Mniejszy, Dom Większy), ale z powodu trudności lokalowych zamiar nie został uskuteczniony.

${ }_{12} \mathrm{~W} 1810$ roku skasowane zostały klasztory benedyktynek radomskich i dominikanek krakowskich z tzw. Domu Mniejszego.

13 Por. M. Borkowska, Zakony, s. 25n.; P. P. Gach, Kasaty zakonów na ziemiach dawnej Rzeczypospolitej i Ślaska 1773-1914, Lublin 1984, s. 18-20; E. Janicka-Olczakowa, Zakony żeńskie w Polsce, w: J. Kłoczowski (red.), Kościót w Polsce. Wieki XVI-XVIII, t. 2, Kraków 1970, s. 764. 
tylko dziewczęta mieszkające $\mathrm{w}$ internacie klasztornym, ale też dochodzące. Miało to związek ze zmianą statusu szkół z klasztornych na normalne, przejęciem ich pod nadzór władz świeckich i współfinansowaniem w części lub całości z budżetu państwowego. Drugą grupę stanowiły szkoły klasztorne o statusie pensji, pozostające bez wsparcia z funduszy państwowych, mające charakter placówek prywatnych. Przyjmowano tam po kilkanaście uczennic stale mieszkających $w$ pensjonacie i realizowano program nauczania zatwierdzony przez władze świeckie.

Pomimo przeobrażeń politycznych, terytorialnych i oświatowych w ciągu przeszło dwóch wieków we wszystkich szkołach dla dziewcząt, prowadzonych przez zakonnice, realizowano podobny ideał wychowania kobiet.

\section{Wychowanie religijne}

Wychowanie religijne stanowiło podstawę wszelkich podejmowanych działań pedagogicznych, było realizowane we wszystkich szkołach klasztornych, a metody i zakres działań były wszędzie bardzo podobne. Celem było nauczenie powinności chrześcijańskich, wdrożenie do życia w pobożności i rozbudzenie gorliwości religijnej. Owa gorliwość miała szczególne znaczenie w okresie walki z reformacją, ponieważ to właśnie kobiety, poprzez przywiązanie do katolicyzmu i wychowanie w tym duchu swoich dzieci, utrwalały go na ziemiach polskich.

Wychowanie religijne odbywało się poprzez nauczanie, rozwijanie i utrwalanie praktyk religijnych oraz katechizację.

Organizacja życia panien świeckich w szkole klasztornej stanowiła ważny element $\mathrm{w}$ realizacji tych idei. Uczennice rozpoczynały każdy kolejny dzień pomiędzy godziną $5^{00}$ a $6^{00}$, w zależności od szkoły klasztornej, pory roku i dnia tygodnia. Zimą oraz w niedziele i święta pozwalano im nieco pospać, nie dłużej jednak niż pół godziny do maksymalnie godziny. Po przebudzeniu należało szybko wstawać i od razu „myśli kierować ku Bogu", odmawiając modlitwę dziękczynną za spokojny sen i modlitwę błagalną o wsparcie na rozpoczynający się dzień. Zakazane było prowadzenie rozmów, pozdrawiano się jedynie słowami „Niech żyje Jezus”, na co odpowiadano „Na zawsze w sercach naszych" ${ }^{14}$.

Następnie wspólnie z mistrzynią wychowanki odmawiały pacierz, po którym nie obowiązywało milczenie. Krótkie modlitwy towarzyszyły dziewczętom przez cały dzień, odmawiano je przed i po zakończeniu lekcji,

${ }^{14}$ Por. E. Sander, dz. cyt., s. 136; Archiwum Klarysek w Krakowie (dalej AKKr.), rps Przepisy i ustawy zakładu naukowo-wychowawczego ss. klarysek, brak sygn. 
przed i po posiłku oraz przed udaniem się na nocny spoczynek. Codziennym obowiązkiem było uczestnictwo w porannej Mszy św., dotyczyło to nie tylko pensjonarek, ale też uczennic dochodzących. Mszy św. słuchano zazwyczaj w kościele klasztornym, gdzie dziewczętom wydzielono stałe miejsce pobytu. Nie mógł to być chór zakonny ze względu na obowiązującą klauzurę. W niektórych konwentach panny świeckie miały własny chór, co było dobrym rozwiązaniem ze względów bezpieczeństwa ${ }^{15}$. Zwyczaj taki obowiązywał w XVII i XVIII stuleciu u benedyktynek w Sandomierzu i wizytek w Krakowie. Zaś w zreformowanej w 1784 roku szkole w Staniątkach dziewczęta pod opieką nauczycielki świeckiej udawały się do kościoła, a po nabożeństwie wracały według ustalonego porządku do szkoły, zlokalizowanej za furtą klasztorną ${ }^{16}$. Z kolei wychowanki w szkole prezentek krakowskich do 1729 roku brały udział w codziennej Mszy św. w kaplicy klasztornej zwanej domową, a w niedziele i święta chodziły do jezuickiego kościoła p.w. św. Barbary. Tylko w wyjątkowych sytuacjach, takich jak duże mrozy, śnieżyce czy słoty, biskupi pozwalali na uczestnictwo we Mszy św. w kaplicy także w dni świąteczne ${ }^{17}$.

Ponadto dziewczęta odmawiały litanie, nie obowiązywały w tej kwestii żadne ogólne zarządzenia, a praktykę regulowała tradycja. U prezentek W środę odmawiano litanię do Matki Bożej a w piątki do Imienia Jezus ${ }^{18}$. Benedyktynki kongregacji chełmińskiej wprowadziły zwyczaj odmawiania litanii po zakończeniu lekcji popołudniowych, około godziny $16^{45}$, oraz w czasie modlitw wieczornych, przed rachunkiem sumienia ${ }^{19}$. Z kolei uczennice w Staniątkach uczestniczyły w codziennym nabożeństwie przed Najświętszym Sakramentem zaraz po obiedzie ${ }^{20}$, a u wizytek pomiędzy godziną $17^{00}$ a $18^{00}$ „sprawowały oracyje”, połączoną z krótką medytacją ${ }^{21}$.

15 Por. A. Szylar (opr.), Dzieje klasztoru sendomirskigo od roku 1615, Sandomierz 2005, s. 79.

16 A. Szylar, Szkoła dla dziewczat w klasztorze benedyktynek $w$ Staniatkach $w$ dobie reform józefińskich, w: I. Szybiak, A. Fijałkowski, J. Kamińska (red.), Szkoła polska od średniowiecza do XX wieku między tradycja a innowacja, Warszawa 2010, s. 211.

${ }_{17}$ Por. R. Gąsior, T. Matuła, dz. cyt., s. 122.

${ }_{18}$ Archiwum Prezentek w Krakowie (dalej APKr.), rps Dokument wydany 11 VII 1729 r. w Krakowie przez biskupa K. Szaniawskiego, sygn. AI/III-2.

${ }_{19}$ Reguła Świętego Ojca Benedykta z tacińskiego przettumaczona [...], Kraków 1606, s. 141-142. Por. też: K. Górski, M[atka] Magdalena Mortęska i jej rola w reformie trydenckiej w Polsce, „Nasza Przeszłość” 34 (1971), s. 71-74; tenże, Zarys dziejów duchowości w Polsce, Kraków 1986, s. 115.

${ }^{20}$ Archiwum Benedyktynek w Staniątkach (dalej ABSt.), rps Regulamin dla uczennic i wychowanek szkoły w Staniątkach, sygn. 1222.

${ }^{21}$ Archiwum Wizytek w Warszawie (dalej AWiWa), rps Rozporządzenie dla Ich Mość panien naszych świeckich jako się powinny sprawować, sygn. F 1 . 
We wszystkich szkołach klasztornych dziewczęta były nauczane i przyzwyczajane do codziennego odprawiania rachunku sumienia. Tradycyjnie była to ostatnia czynność wykonywana przed udaniem się na spoczynek nocny, po nim obowiązywało bezwzględne milczenie aż do dnia następnego. Rachunek sumienia wiązał się także z przygotowaniem dziewcząt do pierwszej spowiedzi i Komunii św., co stanowiło również jeden z elementów wychowania religijnego, podobnie zreszta jak i przygotowanie starszych uczennic do przyjęcia sakramentu bierzmowania. Do szkół klasztornych przyjmowano też dziewczęta pochodzenia żydowskiego, tutaj nauczano je katechizmu, sposobiono do chrztu i innych sakramentów ${ }^{22}$.

Wszystkie wychowanki były zobowiązane regularnie przystępować do spowiedzi i Komunii św., zapiski źródłowe zawierają wzmianki o różnej częstotliwości tych praktyk. Najwięcej informacji z XVII i XVIII stulecia dotyczy obowiązku comiesięcznej spowiedzi, chociaż w niektórych szkołach w osiemnastym stuleciu zalecana była spowiedź cotygodniowa. Z kolei na przełomie XVIII i XIX wieku coraz częściej pojawiają się adnotacje o konieczności przystępowania do spowiedzi i Komunii św. przynajmniej 3-4 razy w roku, na rozpoczęcie i zakończenie roku szkolnego oraz obowiązkowo w czasie Wielkanocy. $Z$ tego okresu posiadamy też dane na temat organizowania uroczystych inauguracji i zakończeń roku szkolnego, poprzedzanych Mszą św. 23

Spowiedź zawsze organizowano $\mathrm{w}$ dniu poprzedzającym uroczystości, po niej dziewczęta aż do przyjęcia Komunii św. zazwyczaj nie spożywały żadnych posiłków, a nawet na niektórych pensjach obowiązywał zakaz prowadzenia rozmów, dopuszczano tylko krótką wymianę zdań szeptem, i to w sytuacjach koniecznych ${ }^{24}$.

Rozwojowi pobożności i religijności wychowanek miały służyć rytuały związane z obchodami świąt kościelnych. Boże Narodzenie świętowano poprzez wspólne śpiewanie kolęd, przygotowywano jasełka i kolędowano w obrębie klasztoru. W kronikach klasztornych i szkolnych odnajdujemy zapiski na ten temat, a w księgach wydatków pod pozycją „na kolędę” wzmianki o obdarowywaniu uczennic i nauczycielek zakonnych drobnymi sumami pieniędzy, kołaczami i słodkościami. Czas Wielkiego Postu przeżywano w skupieniu, stosowano łagodne posty, wszystkie dziewczęta uczestniczyły w rekolekcjach, po których przystępowano do spowiedzi ${ }^{25}$.

${ }^{22}$ Por. E. Sander, dz. cyt., s. 136; A. Szylar, Działalność, s. 160-161.

${ }^{23}$ AKKr., Ustawy i przepisy zakładu naukowo-wychowawczego ss. klarysek, brak sygn.; A. Szylar, Szkoła dla dziewczat, s. 211.

${ }^{24}$ ABSt., rps Dzieje klasztorne od fundacyi aż dotąd (XIII-XIX w.), sygn 203, s. 288.

${ }^{25}$ Por. A. Szylar (opr.), Dzieje, s. 109; Archiwum Klarysek w Starym Sączu (dalej AKSS), 
W pomieszczeniach mieszkalnych i salach szkolnych na ścianach umieszczano symbole religijne. Przykładowo w szkole u klarysek krakowskich w każdej klasie zawieszony był na ścianie obraz przedstawiający ukrzyżowanego Chrystusa. Często spotykało się też obrazy świętych, wizerunki Chrystusa i Matki Boskiej oraz inne symbole katolickie ${ }^{26}$.

Wychowanie religijne dziewcząt obejmowało też nauczanie katechizmu, modlitw, pieśni kościelnych oraz fragmentów historii biblijnej, a od schyłku XVIII wieku religia stanowiła jeden z przedmiotów szkolnych.

Do czasu reformy szkół nauczaniem dziewcząt zajmowała się wyłącznie mistrzyni panien świeckich. Biskup krakowski Piotr Gembicki w 1643 roku sporządził dla mistrzyń specjalną instrukcję, zalecał aby:

[...] chrześcijańskich powinności uczyła, żeby [dziewczęta] je umiały, punkta im dając, jakoby znać mogły dobrodziejstwa Pańskie, tak duchowne jako i doczesne, i za nie dzięki oddawać, egzaminując każdą z osobna, jak to pojmują. Cnoty Boskie niechaj im objaśnia, to jest wiarę, nadzieję i miłość, na których zbawienie ludzkie zawisło. Także cztery cnoty przedniejsze, albo gruntowne do obyczajów pobożnych należące. Roztropność, sprawiedliwość, męstwo i wstrzemię́liwość, ażeby je zaraz w klasztorze pełniły skutecznie, często z nimi o tym rozmowę miewać powinna, ukazując ich potrzebę, że są środkiem do wypełnienia Bożego przykazania ${ }^{27}$.

Uzupełnieniem przekazywanej przez mistrzynię wiedzy była katechizacja dziewcząt prowadzona przez księży sprawujących opiekę duchowną nad zakonnicami, którzy po niedzielnej i świątecznej Mszy św. objaśniali poszczególne punkty katechizmu. U prezentek dodatkowo w niedzielne popołudnia „po obiedzie w katechizmie i nauce chrześcijańskiej [dziewczęta] ćwiczone będą"28.

Historię biblijną poznawano podczas czytanych w czasie obiadu fragmentów lektur religijnych oraz w trakcie przygotowywanych inscenizacji, powiązanych tematycznie ze scenami biblijnymi i historią życia świętych. Przykładem mogą być inscenizacje teatralne ze szkoły benedyktynek sando-

rps Pamiątka z dawnych czasów przełożeństwa J.P. Konstancji Jordanównej, pismo rejestra J. P. Eufrazji Pelagii Wierzbiecianki sekretarki konwentu, s. 14.

${ }^{26}$ Archiwum Uniwersytetu Jagiellońskiego (dalej AUJ), SI-617. Por. E. Sander, dz. cyt., s. 154.

${ }^{27}$ AKKr., rps Piotr Gemicki z łaski Bożej i Stolicy Apostolskiej biskup krakowski, książę siewierski, wielebnej w Chrystusie Panu Pannie Ksieni i wszystkiemu zgromadzeniu panien zakonnych pod regułą świętej Klary, 1643, sygn. A 17, s. 17-18.

${ }^{28}$ Cyt. za: R. Gąsior, T. Matuła, dz. cyt., s. 383. 
mierskich, gdzie w latach 1764-1770 przygotowano trzy spektakle na temat dziejów Józefa Patriarchy, św. Eustachiusza i św. Aleksego. Były to teksty sceniczne pożyczone od jezuitów z kolegium sandomierskiego ${ }^{29}$.

Od czasu reformy szkolnictwa w zaborze austriackim religia stała się odrębnym przedmiotem nauczania. Lekcje prowadzili zazwyczaj księża, chociaż w niższych klasach władze świeckie pozwalały też nauczać zakonnicom. Jedną z metod nauczania było katechizowanie, polegające na zdawaniu przez osobę nauczająca krótkich pytań i udzielaniu przez uczennicę jak najkrótszych odpowiedzi, bez szczegółowego wnikania w istotę treści ${ }^{30}$.

Program nauczania religii znamy dokładnie z czasów austriackich i Księstwa Warszawskiego. W szkole prezentek od 1803 roku lekcje religii prowadził katecheta, w roku szkolnym 1808/1809 tylko w klasie elementarnej mógł nauczać religii po polsku i po niemiecku, w dalszych już tylko po niemiecku. Od klasy trzeciej religii nauczał w ramach dwóch przedmiotów: rzymskiego katechizmu wraz z tekstami z Pisma św. oraz religii fundamentalnej ${ }^{31}$.

U klarysek w 1815 roku nauka religii prowadzona była od klasy elementarnej do trzeciej. W klasie najniższej na religię przeznaczano dwie godziny tygodniowo, jedna z sióstr uczyła katechizmu mansjonarskiego. Ta sama zakonnica nauczała w klasie pierwszej przez dwie godziny tygodniowo religii z małego katechizmu Fleurego, rozważano wtedy problemy wiary, nadziei i miłości. Na dalszym etapie nauki lekcje religii prowadził ksiądz, w klasie drugiej podczas jednej godziny tygodniowo kontynuował zagadnienia powiązane tematycznie w rozumieniem pojęć nadziei i miłości, a w klasie trzeciej przez trzy godziny w tygodniu omawiał istotę sakramentów i problem sprawiedliwości chrześcijańskiej. Uzupełnienie wiedzy religijnej stanowił przedmiot o nazwie historia święta, realizowany od klasy drugiej w ilości jednej godziny tygodniowo. Celem jego nauczania było zapoznanie dziewcząt z najważniejszymi epizodami historii biblijnej ${ }^{32}$. Na lekcjach korzystano $\mathrm{z}$ różnych tekstów, w tym katechizmów (mansjonarski, Katechizm mniejszy ks. M. Fleury), Żywotów świętych autorstwa Piotra Skargi i dzieł hagiograficznych ${ }^{33}$.

${ }^{29}$ Por. A. Szylar, Działalność, s. 93.

${ }^{30}$ Tenże, Szkoła dla dziewczat, s. 214-215.

${ }^{31}$ AUJ, rps Stan szkół narodowych w Krakowie. Konsygnacja nauk, które w szkołach normalnych św. Jana zwanych z czterech klas i piątej elementarnej składających się dla żeńskiej płci wprowadzonych uczonemi były, 6 VIII 1809, sygn. SI 617.

${ }^{32}$ E. Sander, dz. cyt., s. 60-62.

${ }^{33}$ Por. AUJ, sygn. SI-617; A. Szylar, Działalność, s. 105. 


\section{Nauka moralności i obyczajów}

Nauka moralności i obyczajów stanowiła bardzo ważny element kształtowania osobowości dziewcząt. Celem było wyrobienie charakteru wychowanek w zgodzie z przyjętym wzorcem obyczajowo-moralnym kobiet, opierającym się na wychowaniu religijnym. Moralności chrześcijańskiej uczono w czasie katechizacji, a od końca XVIII wieku realizowano w ramach osobnego przedmiotu o nazwie nauka moralna lub moralność. W sprawozdaniu przesłanym władzom oświatowym przez duchaczki krakowskie czytamy na ten temat: „Nauka zaś moralna zasadza się szczególnie na wysławieniu cnót zdobiących i właściwych płci żeńskiej, jakiemi są: praca, skromność, oszczędność, łagodność, cierpliwość, litość i tym podobnych, równie jak na wystawieniu występków tym cnotom przeciwnych i jakim sposobem osoby skłonne do nich pozbyć się ich mogą" ${ }^{34}$. O ważności tego przedmiotu świadczy fakt, że lekcje moralności odbywały się w szkole duchaczek trzy razy w tygodniu, a prowadziła je przełożona klasztoru.

Do pożądanych cech charakteru, określanych jako „reguły ludzkości”, należały: pobożność, pilność, skromność i posłuszeństwo. W jaki sposób można było je rozwinąć i utrwalić? Przede wszystkim poprzez ćwiczenia, sposób życia, oddziaływanie własnym przykładem i autorytetem. Pobożność kształtowano poprzez wychowanie religijne i uświadamianie tego, co jest grzechem, a co dobrym uczynkiem. Pilność rozwijano poprzez przyzwyczajanie do systematycznego i dokładnego wykonywania obowiązków, sumiennego i starannego planowania oraz wytrwałość we wszystkich dążeniach. Skromność była pożądaną cechą charakteru kobiet, dlatego dziewczęta przyzwyczajano do skromnych strojów i prostych posiłków. Zabronione było używanie wymyślnych ubiorów, obowiązywał prosty krój i ciemny kolor sukien, bez jakichkolwiek ozdób. Za to zwracano uwagę na ich czystość i schludność, podobnie zresztą jak i na higienę osobistą wychowanek, pod pojęciem której rozumiano umyte i gładko uczesane włosy oraz wyczyszczone i krótko obcięte paznokcie. Niedozwolone było treflenie loków i upinanie wymyślnych fryzur. W szkole wizytek dbano, aby z samego rana, jeszcze przed Mszą św. „,były posprzątane kornety nocne, podwłośniki i gotowalnice a same [dziewczęta] mają być zasznurowane i ubrane, ręce umyte,

${ }^{34}$ AUJ, rps Odpowiedź na pismo dana przez ss. kanoniczki, dotycząca szkoły przy klasztorze św. Tomasza, 13 II 1816, podp. Magdalena Nowakowska przełożona PP. Kanoniczek, sygn. SI 626. 
usta wypłukane" ${ }^{35}$. Wdrażano je do dbałości nie tylko o siebie i otoczenie, ale też o poszanowanie mienia własnego i szkolnego.

Za szczególnie pożądaną uważano cnotę posłuszeństwa. Jednym z jej aspektów było kształtowanie świadomej przynależności do danego stanu społecznego, wynikających z tego praw i obowiązków. W przypadku dzieci osieroconych i przeznaczonych w przyszłości do służby nauczano je powinności dobrych służących ${ }^{36}$.

Każdy dzień w szkole klasztornej był ściśle zaplanowany, podzielony na naukę, modlitwę, zabawę i odpoczynek, wychowanka nie mogła mieć czasu niezagospodarowanego. $\mathrm{W}$ ten sposób starano się utrwalić zasadę, że kobieta zawsze powinna być zajęta, zgodnie z przeświadczeniem, iż brak zajęć przyczynia się do rozwijania próżności i zepsucia obyczajów.

Niezwykle ceniono punktualność i bardzo zwracano na to uwagę. Dziewczęta zawsze musiały być gotowe na kilka minut przed planowanym wyjściem, rozpoczęciem zajęć czy udaniem się na posiłek. Wszechobecny dzwonek stanowił sygnał wzywający do kolejnych działań.

Zachowania przy stole, używania sztućców i właściwej konsumpcji uczono podczas spożywanych posiłków. Do sali jadalnej wchodzono powoli parami, każda z dziewcząt zajmowała przydzielone jej miejsce i w ciszy oczekiwała na nałożenie porcji na talerz. Po odmówieniu modlitwy wszystkie wychowanki równocześnie zaczynały konsumowanie posiłku. Zabronione było zamienianie talerzy, wyrywanie sobie lepszych kęsów jedzenia, mlaskanie, kruszenie, rozlewanie potraw i inne niestosowane zachowania. Posiłek należało zjadać w milczeniu, bez pośpiechu, a po zakończeniu usta wytrzeć serwetą i oczekiwać na wspólne opuszczenie sali jadalnej.

\section{Kształcenie intelektualne}

Największe zmiany w zakresie edukacji dziewcząt w omawianym okresie dostrzega się w nauczaniu teoretycznym. Do czasu wprowadzenia reformy oświatowej nie obowiązywały żadne jednolite programy nauczania, kwestie te regulowane były poprzez deklaracje i konstytucje załączone do reguł zakonnych, zalecenia wizytatorów, protokoły powizytacyjne, pisma kierowane do zakonnic przez zwierzchników klasztorów żeńskich i wypracowane wzorce edukacji.

${ }^{35}$ AWiWa, sygn. F 1, s. 3.

${ }^{36}$ AUJ, Przedmioty nauk w szkole płci żeńskiej PP. Franciszkanek u S. Andrzeja podczas danego popisu w Krakowie dnia 25 i 26 lipca 1814, sygn. SI 626. 
Na ich podstawie można dokonać pewnych uogólnień. Podstawę kształcenia intelektualnego dziewcząt w XVII wieku stanowiło czytanie, pisanie, rachunki i nauka katechizmu. Do czasu wprowadzenia reformy trydenckiej nauczano głównie języka łacińskiego, od schyłku XVI stulecia powoli wprowadzano język polski, który w kolejnych dziesięcioleciach dość szybko wyparł łacinę. W niektórych klasztorach uczono łaciny w minimalnym zakresie, poprzez naukę na pamięć tekstów modlitw i pieśni kościelnych. Obowiązywał pewien schemat edukacyjny, najpierw czytanie, dopiero po jego opanowaniu pisanie, a następnie proste rachunki w zakresie dodawania i odejmowania. Nie zawsze go realizowano, ponieważ jeszcze w XVII wieku rodzice oddawali swe córki do szkół klasztornych jedynie w celu wychowania religijnego i moralno-obyczajowego, uważając, iż wiedza intelektualna stanowi dla kobiety rzecz całkowicie zbędną.

Z czasem powyższy kanon uległ zmianie, głównie pod wpływem sprowadzonych z Francji wizytek i benedyktynek-sakramentek oraz przemian obyczajowych, dokonujących się w mentalności społecznej. Już w II połowie XVII wieku modny stawał się język francuski, wizytki nauczały go w swoich szkołach, przyjmując na edukację dziewczęta z najzamożniejszych i najbardziej wpływowych rodów magnackich. W XVIII stuleciu język francuski stanowił już normę kształcenia arystokratek, a od połowy stulecia nauczano go także w wielu szkołach klasztornych ${ }^{37}$. Nawet jeśli mniszki same go nie znały, zatrudniały guwernantki, które za odpłatnością udzielały lekcji. Podobnie było z językiem niemieckim, stanowił on dodatkowy przedmiot, nauczany wyłącznie na życzenie rodziców uczennic. Zainteresowanie nim dostrzegamy szczególnie w zachodniej części Małopolski, w klasztorze norbertanek w Imbramowicach oraz w niektórych klasztorach krakowskich. Miało to związek z sąsiedztwem z obszarami niemieckojęzycznymi i faktem, iż do szkół klasztornych coraz częściej trafiały dziewczęta pochodzenia mieszczańskiego. Przykładowo w 1747 roku do Imbramowic ,przyjechała [...] na język niemiecki jejmość panna Domska z Krakowa" ${ }^{38}$, a w 1798 roku przyjęto do tej samej szkoły pannę Dobiecką „na edukacyją francuskiego, niemieckiego języka i grania"39. Od II połowy XVIII stulecia w szkołach klasztornych zaczęto wprowadzać naukę geografii, utrwaliło się bowiem

${ }^{37}$ Por. A. Szylar, „Naprzód zaraz wstanq kiedy ich obudzq...” czyli panny świeckie na edukacji u wizytek warszawskich $w$ XVIII wieku (w druku).

${ }^{38}$ Archiwum Norbertanek w Imbramowicach (dalej ANI), rps Historia domowa klasztoru imbramowskiego [...] w roku Pańskim 1741 zaczęta (1741-1758), sygn. A 28.

${ }^{39}$ ANI, rps Kronika klasztoru ss. norbertanek w Imbramowicach za lata 1797-1917, sygn. A 34 . 
przekonanie, iż bez jej znajomości ,ani gazet rozumieć, ani dyskursu z rozumnymi ludźmi prowadzić nie można"

Ponadto wprowadzone zostały lekcje tańca i gry na różnych instrumentach muzycznych, szczególnie fortepianie i gitarze. Były one nadobowiązkowe; jeśli nauczaniem zajmował się metr lub guwernantka, to również dodatkowo płatne. Rodzice, wysyłając córki do szkół klasztornych, zawsze mieli możność wyboru nauczanych przedmiotów dodatkowych.

Zmiany w zakresie nauczania wdrażane były od lat 80 . XVIII wieku na obszarze zaboru austriackiego. Polegały one na wprowadzeniu jednolitych programów nauczania i przypisaniu do danego poziomu edukacji konkretnych treści. Dla prześledzenia wprowadzonych zmian posłużymy się zestawieniem przedmiotów nauczanych w szkole prezentek w 1809 roku w klasach od elementarnej do czwartej. Na poziomie elementarnym nauczano religii oraz sylabizowania i czytania po polsku i niemiecku, w klasie pierwszej religię wykładano już w dwóch językach, uczono czytania i pisania po polsku i niemiecku wraz z początkami ortografii, wykonywano praktyczne ćwiczenia po niemiecku oraz wprowadzono rachunki. Program w klasie drugiej i trzeciej był dość rozbudowany; oprócz katechizmu rzymskiego pogłębiano znajomość języków niemieckiego i polskiego w zakresie czytania, pisania, gramatyki i znajomości ortografii; pisano dyktanda, uczono rachunków, ponadto wprowadzono nowe przedmioty, w klasie drugiej ,thumaczenie i opowiadanie historyi obyczajności tyczących się" a w klasie trzeciej naukę moralną. Od klasy czwartej uczono też geografii, historii powszechnej i rysunków ${ }^{41}$. Większość lekcji prowadzono po niemiecku. Dominująca rola tego języka ustała po włączeniu Galicji Zachodniej do Księstwa Warszawskiego w 1809 roku. W tej samej szkole prezentek w 1812 roku naukę we wszystkich klasach prowadzono w języku polskim. Na etapie początkowym uczono czytania, rachunków ustnie, katechizmu, nauki o zmysłach i zgłoskowania, w klasie pierwszej doskonalono czytanie, dodano kaligrafię, rachunki w zakresie czterech podstawowych działań, geografię i naukę moralną. W klasie drugiej kontynuowano wcześniej nauczane przedmioty, ale też wprowadzono dodatkowe, obejmujące wiedzę z zakresu historii starożytnej, znajomości miar i wag, podobnie zreszta jak i w klasie czwartej, gdzie nauczano stylu pisania listów, historii Polski, analizowano fragmenty dzieł wybranych autorów polskich i obcych, wykonywano tłumaczenia różnych utworów i uczono

${ }^{40}$ Cyt. za: M. Borkowska, Życie codziennie w polskich klasztorach żeńskich w XVII-XVIII wieku, Warszawa 1996, s. 63.

${ }^{41}$ AUJ, rps Konsygnacya nauk, które w szkołach normalnych S. Jana zwanych z 4 ch klas i piąty elementarny składających się, dla żeńskiej płci wprowadzonych uczonemi były 1809 r., sygn. SI 617. 
zasad sporządzania rysunków. Dodatkowo można było uczęszczać na lekcje z języka francuskiego i niemieckiego oraz gry na instrumentach muzycznych; zajęcia te były odpłatne ${ }^{42}$.

Nawet tak pobieżna analiza programów nauczania wskazuje na głębokie przeobrażenia w procesie nauczania dziewcząt, polegające przede wszystkim na rozszerzeniu zakresu przedmiotów i materiału obowiązkowego, przewidzianego do realizacji na danym poziomie nauczania. Był to program dość trudny, raczej dla zdolnych i pracowitych uczennic, ukończenie pełnego cyklu kształcenia osiagane było tylko przez nieliczne dziewczęta. O przejściu do następnej klasy decydował stopień opanowania materiału i wiek uczennicy, niekiedy młodsze wychowanki pozostawiano w tej samej klasie pomimo znacznych postępów w nauce, gdyż uważano, iż są zbyt młode i nie poradzą sobie w klasie wyższej. Nie precyzowano też czasu pobytu w jednej klasie. Jak wynika z analizy materiałów źródłowych, mógł on wynosić nawet 3-4 lata. Stąd nawet kilkuletni pobyt w szkole mógł oznaczać ukończenie zaledwie jednej czy dwóch klas.

\section{Roboty kobiece}

Niezmiernie istotnym elementem wychowania dziewcząt w szkołach klasztornych była nauka tak zwanych robót kobiecych, nazywanych też domowymi. Wdrażaniu do ich wykonywania i nauce umiejętności o charakterze praktycznym przypisywano nawet większe znaczenie, aniżeli wiedzy intelektualnej. Wynikało to z przekonania, iż ubogie uczennice będą mogły dzięki temu zapewnić sobie utrzymanie, a zamożniejsze w sposób świadomy prowadzić dom, zarządzać służbą i kontrolować wydatki.

W ustawach obowiązujących w szkole prezentek czytamy, że siostry powinny dbać, aby dziewczęta „miały wychowanie dobre i z młodości ćwiczone były nie tylko w bojaźni Bożej, w uczciwych i chrześcijańskich obyczajach, ale też i w robotach powierzchownych, stanowi panieńskiemu należących" ${ }^{43}$. Podobnie było u wizytek, gdzie należało ,zaszczepić i wpoić uczennicom ducha bojaźni Bożej i szacunek do pracy"44, zaś w szkole na Zwierzyńcu siostry powinny dbać, aby ,panienki w rozmaitych robotach ręcznych zosta-

${ }^{42}$ AUJ, Spisanie profesorek profesorów przez których dawane były następujące objekta w szkołach żeńskiej św. Jana dnia 19 lipca roku 1812, sygn. SI 626.

${ }^{43}$ Ustawy Domu Panieńskiego Ofiarowania Najświętszej Panny Maryjej podług Reguły Świętej Eufemii opisane z małym przydatkiem niektórych punktów w Krakowie na Szpitalnej ulicy, zatwierdzone przez bpa A. Trzebnickiego 13 I 1660, Kraków 1698, s. 28.

${ }^{44}$ Cyt. za: B. Fabiani, Warszawska pensja panien wizytek w latach 1655-1680, „Warszawa XVI-XVII wieku" 2 (1977), s. 182. 
ły ćwiczonemi" ${ }^{45}$. Kazimierz Wohlfeil, pełniący w latach 1802-1810 funkcję generalnego inspektora szkół ludowych z ramienia władz austriackich, twierdził, iż nauczenie dziewcząt właściwego planowania pracy w domu i gospodarstwie, porządku w ewidencji posiadanych sprzętów, prowadzenia rachunków oraz umiejętności wykonywania wszelkich prac domowych stanowić powinno zasadniczy element wychowania dziewcząt. Uważał, iż tak zwany dozór „będąc duszą każdego gospodarstwa nie zależy na skrzętnem gderaniu bez celu, ale na dopilnowaniu, ażeby powierzona lub wyznaczona podległej osobie robota była w czasie przyzwoitym wykonana" ${ }^{46}$.

Aby właściwie przygotować dziewczęta do roli „pań domu”, należało je nauczyć umiejętności praktycznych, poprzez przydzielanie do wykonania konkretnych zadań. W ciągu dnia poświęcano tym zajęciom przynajmniej dwie godziny, a po zreformowaniu szkół wprowadzono przedmiot o nazwie roboty i nauczano go kilka godzin tygodniowo.

We wszystkich szkołach klasztornych dziewczęta przez cały omawiany okres nauczano haftowania i szycia. Na pensji u wizytek wykonywano hafty i koronki, zaznajamiano uczennice ze sztuką cerowania ${ }^{47}$. U norbertanek na Zwierzyńcu na roboty ręczne przeznaczano dużo czasu, uczono panny świeckie szycia, haftowania, przędzenia, a kunszt hafciarski zakonnic można do tej pory podziwiać dzięki zachowanym wytworom, datowanym na wiek XVII i XVIII ${ }^{48}$. Klaryski krakowskie nauczały swoje wychowanki dziergania ręcznego i tamborkowego, haftu na kanwie i „ząbkach”, „tak w kolorach jak i szydełkowe[go], jak i koronkowe[go], jak to atłasikowe[go]" ${ }^{49}$. Wykonywanie haftów i koronek było zajęciem dość elitarnym, do bardziej powszechnych należało szycie. Dzielono je na lekkie i ciężkie, bieliźniarstwo, szycie białe i szycie sukien, a zakres nauki różnych jego rodzajów zależał od klasztoru, wieku dziewcząt i życzeń rodziców. W instrukcjach dla wizytek warszawskich czytamy, iż mistrzyni może uczyć dziewczęta szyć „chusty i tym podobne rzeczy, a to dla nauki”, ale tylko te panny, ,które nie są obcią-

${ }^{45}$ AUJ, rps K. Wohlfeiel do Prześwietnej Komisji Akademickiej 16 VIII 1809, sygn. SI 617.

${ }^{46}$ Biblioteka Jagiellońska (dalej BJ), rps Uwagi niżej podpisanego nad wychowaniem panienek w klasztorach krakowskich, 1803, sygn. 5171/36, k. 304.

${ }^{47}$ B. Fabiani, dz. cyt., s. 180; AUJ, Raport o egzaminach i popisach publicznych szkó w objęciu miasta Krakowa znajdujących się [...] dnia 1 go lipca 1815 roku rozpoczętych, a 25 tegoż miesiąca i roku skończonych przez Michała Dymidowicza Konsyliarza Dyrekcji Edukacyi Narodowej, członka Dozoru Szkolnego Dep[artamen]tu Kraków [...], sygn. S I 620.

${ }^{48}$ A. Rybak, H. Otorowska Wrońska, dz. cyt., s. 11.

49 AUJ, Przedmioty nauk w szkole płci żeńskiej PP. Franciszkanek u S. Andrzeja podczas danego popisu w Krakowie dnia 25 i 26 lipca 1814, sygn. SI 626. 
żone inszemi zabawami" ${ }_{50}$. Jeśli uczennica miała dużo dodatkowych zajęć, poprzestawano zapewne jedynie na nauce haftów i koronek. Ważną umiejętnością było przędzenie na kołowrotkach i ,kręcenie nici”, podczas inspekcji w szkołach krakowskich wizytator nakazał zakupienie dodatkowych kołowrotków, aby wszystkie uczennice miały możliwość posługiwania się nimi. Ponadto w protokołach egzaminacyjnych spotykamy informacje o wykonanych przez dziewczęta pończochach, robotach szydełkowych i na drutach ${ }^{51}$.

Kolejną grupę umiejętności stanowiły zajęcia związane z prowadzeniem kuchni i apteczki domowej. Dziewczęta należało nauczyć wypiekania chleba, wytwarzania octu, sporządzania nalewek, przygotowania domowych wypieków, konfitur i suszów. W szkołach zlokalizowanych w klasztorach położonych na wsiach zalecano nauczanie ogrodnictwa, uprawy różnych roślin i ziół, wykorzystywanych w konsumpcji i lecznictwie. Do pożytecznych umiejętności należało przygotowanie krochmalu, wytwarzanie mydła, farbowanie płócien i nici oraz pranie odzieży ${ }^{52}$. Nie jesteśmy w stanie dokładnie określić, w jakim stopniu zalecenia te, sporządzone na początku XIX wieku przez wspomnianego już inspektora szkół ludowych, zostały wdrożone. Faktem jest, iż mają one charakter umiejętności niezwykle użytecznych, określających powinności ówczesnych kobiet w rodzinie i społeczeństwie.

$*$

Konkludując, można stwierdzić, iż ideał wychowania dziewcząt kształtował się w oparciu o wychowanie religijne, moralno-obyczajowe, naukę intelektualną i praktyczną znajomość tak zwanych robót kobiecych. W szkołach klasztornych przygotowywano dziewczęta do roli żony i matki, która będzie zgodnie z zasadami religii katolickiej i moralności chrześcijańskiej wypełniać wszystkie swoje powinności. Znajomość zasad zachowania i obowiązujących w społeczeństwie obyczajów stanowiła istotny element kształtowanego wzorca osobowego kobiety. Ważne były też umiejętności praktyczne, związane z wykonywaniem zajęć należących do powinności kobiet. Dużo mniejsze znaczenie przypisywano wykształceniu, chociaż widoczna jest ewolucja poglądów na ten temat. Od wiedzy na poziomie elementarnym, poprzez nauczanie języków obcych, elementów geografii, rysunku, muzyki aż po realizację rozbudowanych, narzuconych przez władze świeckie programów nauczania. Podkreślić należy, iż zgodnie z duchem reform oświeceniowych starano się stworzyć możliwość edukacji zarówno uczenni-

${ }^{50}$ B. Fabiani, dz. cyt., s. 180.

${ }^{51}$ BJ, sygn. 5171/36, s. 304-305; AUJ, Szkoła św. Andrzeja 1814, sygn. SI 626.

${ }^{52}$ BJ, sygn. 5171/36, s. 304-305. 
com zamożnym, jak i uboższym, oferując tym ostatnim naukę umiejętności pozwalających im w przyszłości zarabiać na własne utrzymanie. Pozostałe dziewczęta mogły realizować cały program nauczania i zdobyć wykształcenie obejmujące maksymalny zakres edukacji kobiet. Najpełniej ideał wychowania dziewcząt scharakteryzowała w 1790 roku ksieni cysterek w Ołoboku stwierdzając:

Cel i osnowa edukacji: [...] Mieć umysł na tyle oświecony, aby mu nie schodziło na wiadomości wszystkiego, co sobie może być pomocnym i właściwie potrzebnym dla dopełnienia różnych stanu swego obowiązków; mieć przy rozumie tyle oświecenia, aby mógł poznawać, co jest użytecznym, a co szkodliwym, co przystojnym, a co nieuczciwym; tak ukształcone serce, aby w pełnieniu obowiązków religii i stanu swego znajdować rozkosz; mieć tyle poloru i zaszczycać się takimi talenty, posiadać tyle pięknych przymiotów, aby się stać osobą miłą i interesującą w towarzystwie ludzi z którymi żyje $[\ldots]^{53}$.

\section{The Ideals of Education in Convent Schools for Girls in the Period following the Council of Trent until the Early Nineteenth Century (Summary)}

This paper discusses the upbringing and education of laic girls in convent schools from the last decade of the 16th century until 1815. The analysis is based on archival materials and literature. It focuses on the educational process carried out on the territory of Lesser Poland (Matopolska) which, as a result of the partitions of Poland, was initially partly within the Habsburg Empire and later, a part of it was incorporated into the Duchy of Warsaw. In order to thoroughly analyse the issues raised in the paper, the convent schools that functioned in Lesser Poland are compared to schools from other areas of the Republic. The paper focuses on the problems of girls' education in convent schools belonging to four types of orders: the Order of the Virgins of the Presentation of the Blessed Virgin Mary (zakon prezentek), the Order of Saint Claire (zakon klarysek), the Norbertine Order (zakon norbertanek) and the Order of Saint Benedict (zakon benedyktynek). Among 18 female religious orders (with 154 monasteries in total) that functioned in 1772 on the territory of the Republic, only two did not run monastic schools for girls.

The schools' main postulates were: educating girls in the spirit of Catholicism, shaping their morals and developing their devotion, as well as teaching them the

${ }^{53}$ Cyt. za: M. Borkowska, Życie, s. 63. 
so-called women's work related to household chores and running a household. Such ideals of education were implemented in all schools. Their programs only differed when it came to teaching Polish, foreign languages, maths, music, dance and others skills. Such programs had an undeniable influence on the girls' personality and aimed to prepare them for their future social role.

When comparing the patterns in girls' education during the time of partitions, some changes can be noticed. The schools' character was conditioned by the shift of supervision over schools away from secular authorities, the introduction of the classroom system and the use of the same curriculum in each school of a particular type. 